\title{
The Conflicts and Harmony between Taxation and Family Policy in Finland
}

\author{
RIITTA AUVINEN \\ Research Director, Docent \\ The Population Research Institute
}

Young families have become a major topic of interest in the social policy of Finland because of the country's low fertility. The future of the population in tomorrow's Finland is essentially determined by the welfare of families with children today. Until now taxation policy has not been considered a means of affecting fertility. In order to make people more willing to have children not only social policy but also taxation policy must be harnessed. In taxation children are more or less considered a consuming unit which the parents should support for almost twenty years. Although the material support given to families with children is fairly good in Finland when compared internationally, the equalization of family costs and securing just taxation for families still ought to be developed.

About 80 percent of the population were part of a family in 1984 . Hence living as couples and in a family is still common despite all contrary information. Fourfifths of the age group of 25-44-year-olds are married or cohabiting. About 60 percent of the population are supporters of children when young people who continued their studies are included among those being supported. More than 85 percent belong to the economically active population. Approximately one-half of the labor force is composed of child supporters. Only 15 percent of the population never support children (Peräläinen, 1985, 3-4).

In recent years, according to the tax statistics, child supporters have paid about 45 percent of the taxes paid by natural persons. However, this figure does not tell the whole truth about the proportion of taxes paid by families with children because the tax statistics do not include those supporters who have children over 16 years of age. On the average in the society of today the supporting of children ends when the child is 20 because today the majority of young people under this age are students and consequently at least to some extent dependent on their parents. The supporters pay relatively more taxes in this phase of life than when supporting minors because tax deductions which are granted for children who are studying are insignificant. It can be roughly estimated that the real number of families with children to support is about 15 percent higher than the tax authorities admit (Peräläinen, 1985, 85). It is quite clear that the definition of a child in the tax legislation derives from the agrarian society which we have left behind us long ago. This definition should be revised in order to meet the present circumstances and facts.

If a family with children is defined as a family with a child under the age of 20 , it can be estimated that the supporters' taxable income comprises an average of about one-half of a natural person's total income and that the child supporters pay a little over one-half of direct taxes paid by natural persons. In the light of this information, taxation policy for families with children is considerably more relevant than income transfers because these families clearly pay over one-half of the income transfers. It can be asked with good reason whether it is sensible to enlargen the income 
transfers in order to solve the economic problems of families with children, because they themselves mainly pay for the transfers. Consequently, for families, social policy would only mean the transferral of funds from one pocket to another with they themselves financing it.

The proportion of indirect taxes on disposable income is somewhat larger in families with children than in other households because consumption expenditures in these families make up a larger proportion of the disposable income than on the average. Especially families with small children, that is young families, and households with many members have to pay more indirect taxes than the average. The burden of indirect taxes would probably be even heavier than it is now in households with many members, i.e. in families with many children, if food would not include less indirect tax than other goods. This can be regarded as an advantage to families with children.

As families with children have to pay a larger proportion of indirect taxes of their consumption expenditures than on the average, it is probable that family supporters pay over one-half of the indirect taxes of all households. Consequently we must note that families with children do not receive any special deductions from the burden caused by indirect taxes. As they have to pay more of these taxes than on the average, it can be said that indirect taxation deviates unfavorably from the state income and property taxation, municipal taxation, and different kinds of tax-like payments, because in these some deductions are given to families with children. This is not a trivial matter as natural persons now pay taxes by indirect taxation approximately as much as by direct taxation.

Married couples supporting a child have a higher income on the average than childless couples. This may be mainly due to the fact that in the majority of families with children both parents are gainfully employed, although some couples may have a small income or income only part of the year. In only about 6 percent of all married couples one of the spouses does not have any income. Also the tax authorities favor a pattern where both the spouses are gainfully employed. In order to maintain a family in Finland today, it is almost a necessity that both parents are gainfully employed.

However, the more children a family has, the more often there is only one supporter in it. Mostly there are couples supporting small or school-aged children. The spouse who has a smaller income stays at home to take care of the children, in spite of the fact that the economic importance of the spouse deductions which are granted in the taxation have weakened in the course of the years. Consequently a childless gainfully employed couple can today be defined as well-off on the basis of taxation practice. This can also be seen in property taxation. Childless couples pay over onehalf of the property taxes, supporters 30 percent, and the unmarried 20 percent. However, if we still take into account parents whose children are continuing their studies, i.e. parents who are in that phase of their life cycle when their income is highest, it can be estimated that child supporters pay about 40 percent of property taxes. The renewal of the population or human reproduction and renewal of capital focus on quite different members of society. In order to secure the tax basis also in the future, it is necessary to consider whether this kind of polarization between different phases of life and different groups of society is justified. Sometimes it has been said that Finland practices a sunset social policy. The taxation policy also seems to favor this policy. A leading basic paradigm is still the fairness of taxation of families with children interpreted so that it would have a positive influence on fertility.

Young families which have a higher education compared with previous generations and consequently a higher nominal income are severely taxed in the phase of life where they are starting to build a family, purchase a dwelling, and possibly pay 
off student loans. Further, the cost of day care for a family with two children in the Helsinki metropolitan area is already as high as the net minimum wage (Veronmaksajain Keskusiiitto, Verouudistusohjelma, 1986). Hence, it is no wonder that fertility is as low as it is. The "yuppies» would rather talk about being single, and only 1.3 children are born per family in the Helsinki metropolitan area. Over one-half of the women in the metropolitan area who are under 30 years and in the best childbearing age are still childless. We have developed in a direction where the family as a basic unit of society is becoming a marginal phenomenon. The social policy which has been practiced in Finland is responsible for this trend.

In recent years efforts have been made to develop children's day care in a direction which gives more freedom of choice and treats people who are in different phases of life more equally. Parents whose children are in inexpensive municipal day care feel really lucky, whereas parents who have to use insecure and expensive private day care services which are not deductable from taxes certainly often ponder if taxation concerning expenses caused by income earning really has kept up with the current living situation of families with children. When even restaurant bills are in some cases considered expenses connected to income earning, it is illogical that the indispensable and often unreasonably high costs of children's private day care cannot be accepted as expenses caused by income earning.

The economic burden caused by children in a family is heaviest both at the beginning and the end of childhood. With regard to the consumption and taxation of young families with children, families taking the responsibility for the reproduction of the population, it would probably not be advantageous for the emphasis of taxes to be changed from direct to more indirect taxation. The essential consumption such as food, education and necessary costs of traffic and housing would be outside of taxation. Further, the stamp duty tax when purchasing a dwelling ought to be decreased. Families should be able to move to a large dwelling when they grow.

The practice of interest deductions for housing loans is quite peculiar. According to the law a married couple can deduct interests on the loan from their taxable income up to 25000 FIM. This sum corresponds to the interest on a loan for half of the sum needed to pay for a dwelling for a small family in the Helsinki metropolitan area. However, a cohabiting couple can have this deduction doubled, although the amount of the loan is the same, as they are considered two separate taxation objects. This kind of taxation may be unintentional because it is difficult to believe that the State would consciously like to favor consensual unions at the expense of juridically more prescribed legal marriages. However, this deduction is essentially important from the taxpayer's standpoint, at least if it can be used to a maximum. Taxpayers are not treated equally.

In addition, without taking a moral stand on the matter, taxation favors the deviant party contrary to other social legislation. One can only wonder why young people are getting married at all. Probably because citizens know quite little on the average, even too little, about their own taxation and the possibilities which are offered by taxation for achieving their goals. Young people and young families are usually less familiar with taxation than with income transfer policy. It is too complicated, bureaucratic, and strange. However, there are always people who are aware of this complicated system and take advantage of the loopholes which may have been planned unintentionally by the tax authorities. However, this is not fair and does not favor the stable development of society.

When planning a taxation reform in our country we should realize and thoroughly consider whether we want to take a stand through taxation on the biological reproduction of the population. If we want to raise fertility in our country, small separate 
corrections in tax policy are not enough. Instead we have to ask how the tax authorities could favor families with children which still take the responsibility of giving birth to children. And this truly concerns young families because two out of three children in Finland are born to under-30-year-old parents who have to save dwelling, pay off student loans, and cope with child day care costs at same time. Should we solve the problem, for instance, so that every citizen would have the right to earn a certain basic living tax-free, e.g. as much as the level of the present income security is. In this case the student deduction and possibly other tax deductions would be left out and the taxation would become more simple. In addition to this new planning and allocation of taxes would be needed.

However, when reforming taxation we have to remember that the Finns are already learning to plan taxation and that is why no shortsighted measures should be considered. The tax authorities, in particular, are expected to have given careful consideration to their aims and to have a clear philosophy behind them. The tax authorities should be trustworthy. A family's possibility to plan is based on this trust. However, we have to remember that if the tax authorities cannot plan an environment favorable to children as a part of social policy, these children will not be born at all as a result of the family's own planning today. Children do not fit into a life where the parents already find themselves spread too thin.

\section{References}

Aura, Matti. (1986). Esitelmä verotuksen uudistamisesta LTK:n edustajiston syyskokouksèssa. (Paper on the reforming of taxation presented at the meeting of the Employers' Confederation of Service Industries in autumn 1986).

Peräläinen, Antero. (1985). Lapsiperheet - pieni vähemmistö vai valtaenemmistö. (Families with children - a small minority or a large majority). Väestöntutkimuslaitoksen julkaisusarja D, nro 14. Helsinki, Finland: Väestöntutkimuslaitos.

Veronmaksajain Keskusliitto (Taxpayers' Association). (1986). Mielipidetutkimuksia verotuksesta. (Opinion studies on taxation).

Veronmaksajain Keskusliitto (Taxpayers' Association). (1986). Verouudistusohjelma. (Tax reforming program, proposal for the Finnish Government). 